\title{
Adaptation of the human Cell Line Activation Test (h-CLAT) to Animal-Product-Free Conditions
}

\author{
Alexander Edwards, Lottie Roscoe, Christopher Longmore, Fiona Bailey, Bushra Sim and Carol Treasure \\ XCellR8 Ltd, Techspace One, Sci-Tech Daresbury, Daresbury, Cheshire, UK
}

\begin{abstract}
Skin sensitizers are substances that can elicit allergic responses following skin contact. The process by which this occurs, i.e., skin sensitization, is a series of key events that form an adverse outcome pathway (AOP). Key event 3 in the AOP is dendritic cell activation that can be modelled by the human Cell Line Activation Test (h-CLAT) and is typified by changes in cell surface markers CD54 and CD86 in dendritic cells. The h-CLAT is accepted at a regulatory level (OECD Test Guideline 442E) and can be used to assess skin sensitization potential as part of an integrated approach to testing and assessment (IATA).

Stakeholders in the cosmetics and chemical industries have scientific and ethical concerns relating to use of animal-derived material and have communicated a strong preference for fully human-based in vitro methods. Therefore, we adapted the h-CLAT to animal-product-free conditions and validated the adapted method with the proficiency panel substances listed in Annex II of TG 442E using 3 independent batches of pooled human serum. The modified method showed equivalence to the validated reference method (VRM), as all proficiency substances were correctly classified. Comparable values for CV75 (concentration yielding 75\% cell viability), EC150 and EC200 (concentration yielding $\mathrm{RFI}$ of $\geq 150$ for CD86 and $\geq 200$ for CD54) were obtained. Data generated using the adapted method may be used in European REACH submissions, provided the proficiency data is included. We are seeking formal inclusion of the adaptation into TG $442 \mathrm{E}$, enabling compliance with global regulations.
\end{abstract}

\section{Introduction}

Skin sensitization is a multi-faceted process that has been described as an adverse outcome pathway (AOP). Following skin penetration, chemicals may bind covalently to skin proteins (key event (KE) 1), followed by the activation of keratinocytes (KE 2) and dendritic cell (DC) activation (KE 3). Dendritic cells migrate to the lymph nodes and induce the proliferation of T-lymphocytes (KE 4). Due to current legislation, including the European Cosmetics Regulation 1223/2009 and REACH (Registration, Evaluation, Authorisation and Restriction of Chemicals), alternatives to traditionally used animal models have been sought in order to determine the skin sensitization potential of test chemicals. In vitro methods that can be used to model KE 1-3 have been adopted for use in regulatory submissions as OECD test guidelines; OECD TG 442C: DPRA (Gerberick et al., 2004), OECD TG 442D: KeratinoSens ${ }^{\mathrm{TM}}$ (Natsch et al., 2011), and OECD TG 442E: h-CLAT (Ashikaga et al., 2006; Sakaguchi et al., 2006; EURL ECVAM, 2012).
The h-CLAT method models KE 3 and quantifies the changes in cell surface marker expression on the THP-1 cell line, a human monocytic leukemia cell line, which mimics DCs. Surface markers CD54 and CD86 are up-regulated in the presence of skin sensitizers, indicating that DC activation has occurred (Ashikaga et al., 2006). The changes in CD54 and CD86 are detected by flow cytometry (FC) following staining with fluorochrome-tagged antibodies. Concurrent cytotoxicity assessment is carried out using propidium iodide $(\mathrm{PI})$ to assess whether the up-regulated expression of CD54 and CD86 occurs at sub-cytotoxic test chemical concentrations (Sakaguchi et al., 2009). The relative fluorescence intensity (RFI) of the surface markers is determined with respect to the solvent/vehicle control used. The data is assessed using a prediction model to discriminate between sensitizers and non-sensitizers (TG 442E; OECD, 2018b).

The h-CLAT method represents a great advancement in the replacement of animal testing. However, the published protocol currently includes the use of animal-derived cell culture components, i.e., fetal bovine serum (FBS) and bovine serum albumin 
(BSA), as well as antibodies that were originally derived from an animal source.

The mission of XCellR8 is the full replacement of animal testing for cosmetics and their ingredients globally, motivated by an industry requirement to maximize the human relevance of in vitro models, alongside animal welfare considerations. This strategy includes eradication of the significant number of animal-derived components that are still widely used in cell culture methods and contributes to the global adoption of the 3Rs.

Adaptations to the reference h-CLAT method described in OECD TG 442E (adopted July 29, 2016, updated June 27, 2018) were made through the use of human equivalents to enable the complete replacement of animal products for testing KE 3 in the skin sensitization AOP. This involved the replacement of FBS with human serum (HS) and BSA with human serum albumin (HSA). In addition, a custom anti-CD54 and anti-CD86 antibody development project was undertaken with BioRad to yield antibodies that are derived from a non-animal source using phage-display (Human Combinatorial Antibody Library; HuCAL).

Here, we describe the internal validation carried out for the modified method using the $10 \mathrm{~h}$-CLAT proficiency substances for skin sensitization as detailed in Annex II of OECD TG 442E.

\section{Materials and methods}

\subsection{Proficiency substances}

All proficiency substances were purchased from Sigma-Aldrich and selected based upon the criteria detailed in Annex II of OECD TG 442E and supporting information provided in the European Union Reference Laboratory for Alternative Methods to Animal Testing (ECVAM) Human Cell Line Activation Test (h-CLAT) Validation Study Report. 2,4-Dinitrochlorobenzene (DNCB; Sigma-Aldrich, CAS\# 97-00-7) was used as the positive control for the dose finding assay (dose that yields $75 \%$ cell viability; CV75)

Tab. 1: List of all proficiency chemicals used in this study to evaluate the performance of the h-CLAT adapted to animal-product-free conditions

\begin{tabular}{|l|l|}
\hline Proficiency substance & CAS number \\
\hline 2,4-Dinitrochlorobenzene & $97-00-7$ \\
\hline 4-Phenylenediamine & $106-50-3$ \\
\hline Nickel sulphate & $10101-97-0$ \\
\hline 2-Mercaptobenzothiazole & $149-30-4$ \\
\hline $\mathrm{R}(+)$-Limonene & $5989-27-5$ \\
\hline Imidazolidinyl urea & $39236-46-9$ \\
\hline Isopropanol & $67-63-0$ \\
\hline Glycerol & $56-81-5$ \\
\hline Lactic acid & $50-21-5$ \\
\hline 4-Aminobenzoic acid & $150-13-0$ \\
\hline
\end{tabular}

that is carried out as part of the overall h-CLAT testing strategy. Nickel sulphate $\left(\mathrm{NiSO}_{4}\right.$; Sigma-Aldrich, CAS\# 10101-97-0) was used as the positive control for the CD54 and CD86 expression measurement assay that forms the main part of the h-CLAT. Table 1 lists the proficiency panel substances.

\subsection{Cell culture}

THP-1 cells were obtained from ATCC (TIB202). After the first thaw from cryopreservation, the cells were adapted to animalproduct-free cell culture medium. Cells were routinely cultured in RPMI 1640 medium supplemented with 0.05 mM 2-mercaptoethanol (55 mM stock, Gibco) and human serum (pooled human male AB plasma using approximately 50-70 donors per batch, Sigma-Aldrich, non-heat inactivated) to a final concentration of $10 \%$, at $37^{\circ} \mathrm{C}, 5 \% \mathrm{CO}_{2}$, in a humidified atmosphere, to a maximum passage number of 20 . THP-1 cells were passaged before the cell density reached $1 \times 10^{6}$ cells $/ \mathrm{ml}$ in culture as overgrowth affects THP-1 morphology (Mizuno et al., 2008). Population doubling times of new cell batches taken out of cryopreservation were assessed by counting cells every $24 \mathrm{~h}$ for a maximum of $72 \mathrm{~h}$ in line with OECD TG 442E and DB-ALM Protocol No. 158: human Cell Line Activation Test (h-CLAT) ${ }^{1}$.

\subsection{Antibodies and flow cytometry}

Custom anti-CD54 and anti-CD86 antibodies from a non-animal source were produced for XCellR8 (HuCAL, BioRad) using phage display (Knappik et al., 2000). These were conjugated to FITC for use in the h-CLAT in order to detect changes in the cell surface markers. The custom HuCAL antibodies will be made available commercially. Propidium iodide (PI; Sigma-Aldrich) was used to stain dead cells in order to determine viability as per the reference method. Flow cytometry (FC) was carried out using a Merck Guava 6HT-2L 96-well plate-based system.

\section{4 h-CLAT}

\section{Dose finding assay $\mathrm{CV} 75$}

THP-1 cells were seeded at $0.2 \times 10^{6}$ cells $/ \mathrm{ml}$ and cultured for either 48 or $72 \pm 2 \mathrm{~h}$. Prior to starting the assay after the initial seeding time, proficiency substances were solubilized in either complete RPMI cell culture medium or dimethyl sulfoxide (DMSO; Sigma Aldrich) as solvent. Cells were then seeded into 96 well plates at $1.6 \times 10^{5}$ cells/well and dosed with proficiency substances solubilized in the appropriate solvent over an 8-dose range, DNCB positive control $(8 \mu \mathrm{g} / \mathrm{ml})$, DMSO solvent control and RPMI culture medium solvent control. After $24 \pm 0.5 \mathrm{~h}$ the cells were centrifuged and then washed twice with $200 \mu 1$ staining buffer (a.k.a. FACS buffer), which was prepared by adding $0.1 \% \mathrm{w} / \mathrm{v}$ human serum albumin (HSA; Irvine Scientific) to phosphate buffered saline (PBS; Sigma-Aldrich). Cells were then resuspended in $200 \mu \mathrm{l} \mathrm{FACS}$ buffer containing PI $(0.625 \mu \mathrm{g} /$ $\mathrm{ml}$ ) and analyzed on the flow cytometer. The $\%$ cell viability was determined and used to calculate the CV75.

The CV75 assay was performed as described in OECD TG 442E with the following adaptations to animal-product-free conditions:

\footnotetext{
1 https://ecvam-dbalm.jrc.ec.europa.eu/methods-and-protocols/search/h-clat
} 
THP- 1 cells were seeded at $0.2 \times 10^{6}$ cells $/ \mathrm{ml}$ in $25 \mathrm{ml}$ of routine culture medium containing HS and 2-mercaptoethanol (as described in Section 2.2) and cultured for either 48 or $72 \pm 2 \mathrm{~h}$ prior to dosing with proficiency substances. The staining buffer used was prepared using $0.1 \% \mathrm{w} / \mathrm{v}$ HSA.

\section{CD54 and CD86 expression measurement}

THP- 1 cells were seeded at $0.2 \times 10^{6}$ cells $/ \mathrm{ml}$ and cultured for either 48 or $72 \pm 2 \mathrm{~h}$. THP-1 cells between passage number 10 and 19 were used for all experiments. Prior to starting the assay after the initial seeding time, proficiency substances were solubilized in either complete RPMI cell culture medium or DMSO as solvent. Cells were then seeded into 24 well plates at $1 \times 10^{6}$ cells/ well and dosed with proficiency substances in the appropriate solvent over an 8-dose range, $\mathrm{NiSO}_{4}$ positive control $(100 \mu \mathrm{g} /$ $\mathrm{ml}$ ), DMSO solvent control, and RPMI culture medium solvent control. At least 2 independent experiments were used for the final classification for each proficiency substance; within each experiment, a single replicate over an 8-dose range for each substance for each marker (isotype, CD54 and CD86) was assessed. The level of replication and numbers of final independent experiments required are in line with the requirements stipulated in OECD TG 442E for demonstration of proficiency. Where possible, the 8-dose proficiency substance range was based around the CV75 value with the top dose being $1.2 \times \mathrm{CV} 75$, the second highest dose being the CV75 and the remaining 6 doses being 1.2-fold serial dilutions from the CV75. Exceptions to this occurred for $\mathrm{DNCB}, \mathrm{NiSO}_{4}, \mathrm{R}(+)$-limonene and imidazolidinyl urea where dosing ranges were adjusted due to previous data on effective dosing ranges either from the test developers in the ECVAM validation study $(\mathrm{R}(+)$-limonene), internal reactivity check experiments $\left(\mathrm{DNCB}, \mathrm{NiSO}_{4}\right)$ or necessity due to observed cytotoxic effects (imidazolidinyl urea). After $24 \pm 0.5 \mathrm{~h}$ the cells were centrifuged and then washed twice with $200 \mu \mathrm{l}$ staining buffer, which was prepared by adding $0.1 \%$ w/v HSA to PBS. Cells were then resuspended in blocking buffer containing
$0.1 \% \mathrm{w} / \mathrm{v}$ human globulins Cohn fraction II, III (Sigma-Aldrich) in PBS and incubated at $4^{\circ} \mathrm{C}$ for $15 \mathrm{~min}$.

After blocking, cells were resuspended and then split into three aliquots of $180 \mu \mathrm{l}$ in a 96 well U-bottom plate and centrifuged for $5 \mathrm{~min}$ at $250 \mathrm{~g}$. Supernatants were then removed and the FITC conjugated antibodies were diluted appropriately in staining buffer to a volume of $50 \mu \mathrm{l}$ from lot specific stock concentrations (the fixed final concentrations used were: BioRad HuCAL Isotype Control: Control (AbD 05983): 0.015 mg/ml, BioRad HuCAL anti-human CD54 (AbD 28606): $0.0174 \mathrm{mg} / \mathrm{ml}$ and BioRad HuCAL anti-human CD86 (AbD 28492): 0.0105 mg/ml). $50 \mu 1$ of each diluted antibody was then added to each cell pellet as required. After thorough pipette mixing, plates were incubated for $30 \mathrm{~min}$ at $4^{\circ} \mathrm{C}$. After incubation the cells were centrifuged and then washed three times with $200 \mu 1$ staining buffer. Cells were then resuspended in $200 \mu \mathrm{l}$ FACS buffer containing PI $(0.625 \mu \mathrm{g} / \mathrm{ml})$ and analyzed on the flow cytometer.

The geometric mean fluorescence intensity (MFI) from each sample along with the \% cell viability was determined and used with an internally validated excel spreadsheet to determine the relative fluorescence intensity (RFI), which could then be used in the prediction model as described in OECD TG 442E.

The CD54 and CD86 expression measurement was carried out as described for the VRM in OECD TG 442E, with the following adaptations to animal-product-free conditions:

THP- 1 cells were seeded at $0.2 \times 10^{6}$ cells $/ \mathrm{ml}$ in $25 \mathrm{ml}$ of routine culture medium containing HS and 2-mercaptoethanol (as described in Section 2.2) and cultured for either 48 or $72 \pm 2 \mathrm{~h}$, prior to dosing with proficiency substances.

Prior to staining with antibodies or PI the cells were washed in staining buffer prepared as detailed in Section 2.4, Dose finding assay CV75. Anti-CD54 and CD86 HuCAL antibodies conjugated to FITC were used to detect the changes in cell surface markers on the THP-1 cells (see Section 2.3).

The antibodies were diluted in staining buffer prepared using $0.1 \% \mathrm{w} / \mathrm{v}$ HSA as described above.
A

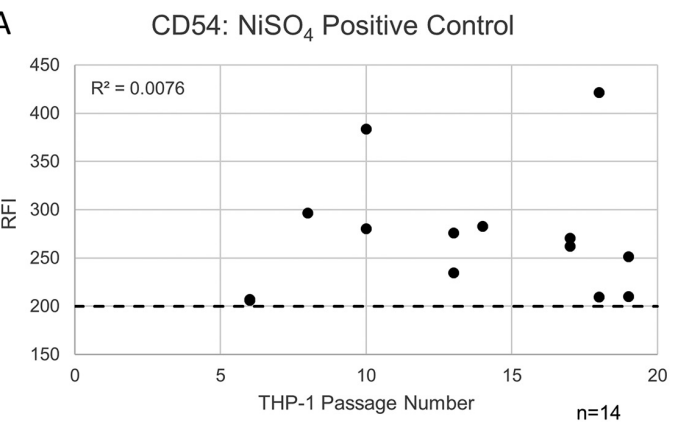

B

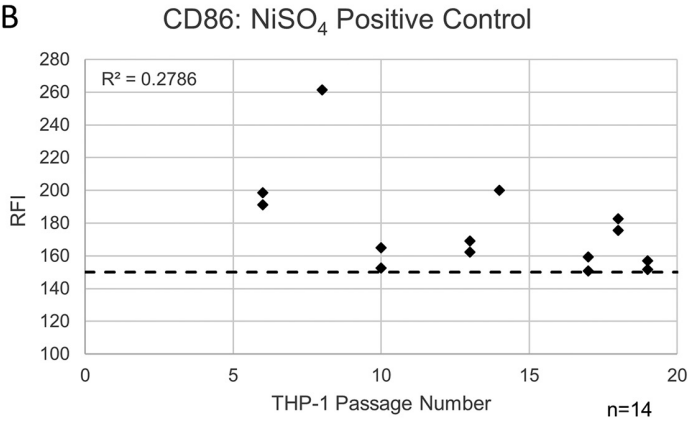

Fig. 1: Relative fluorescence intensity (RFI) values generated by the nickel sulphate positive control across independent studies for A: CD54 and B: CD86

$R^{2}$ values show little correlation between increasing THP-1 cell passage number and the final RFI values $(n=14)$. 
Tab. 2: CV75 values (dose yielding $75 \%$ cell viability, $\mu \mathrm{g} / \mathrm{ml}$ ) derived from 2 independent experiments compared against the reference range from OECD TG $442 E$

\begin{tabular}{|l|l|l|}
\hline Proficiency substance & TG 442E CV75 value reference range $(\mu \mathrm{g} / \mathrm{ml})$ & XCellR8 average CV75 value $(\boldsymbol{\mu g} / \mathrm{ml})$ \\
\hline 2,4-Dinitrochlorobenzene & $2-12$ & 3.2 \\
\hline 4-Phenylenediamine & $5-95$ & 32.6 \\
\hline Nickel sulphate & $30-500$ & 44.4 \\
\hline 2-Mercaptobenzothiazole & $30-400$ & 276.4 \\
\hline $\mathrm{R}(+)$-Limonene & $>20$ & $>500$ \\
\hline Imidazolidinyl urea & $25-100$ & 14.2 \\
\hline Isopropanol & $>5000$ & $>5000$ \\
\hline Glycerol & $>5000$ & $>5000$ \\
\hline Lactic acid & $1500-5000$ & 1546.4 \\
\hline 4-Aminobenzoic acid & $>1000$ & $>1000$ \\
\hline
\end{tabular}

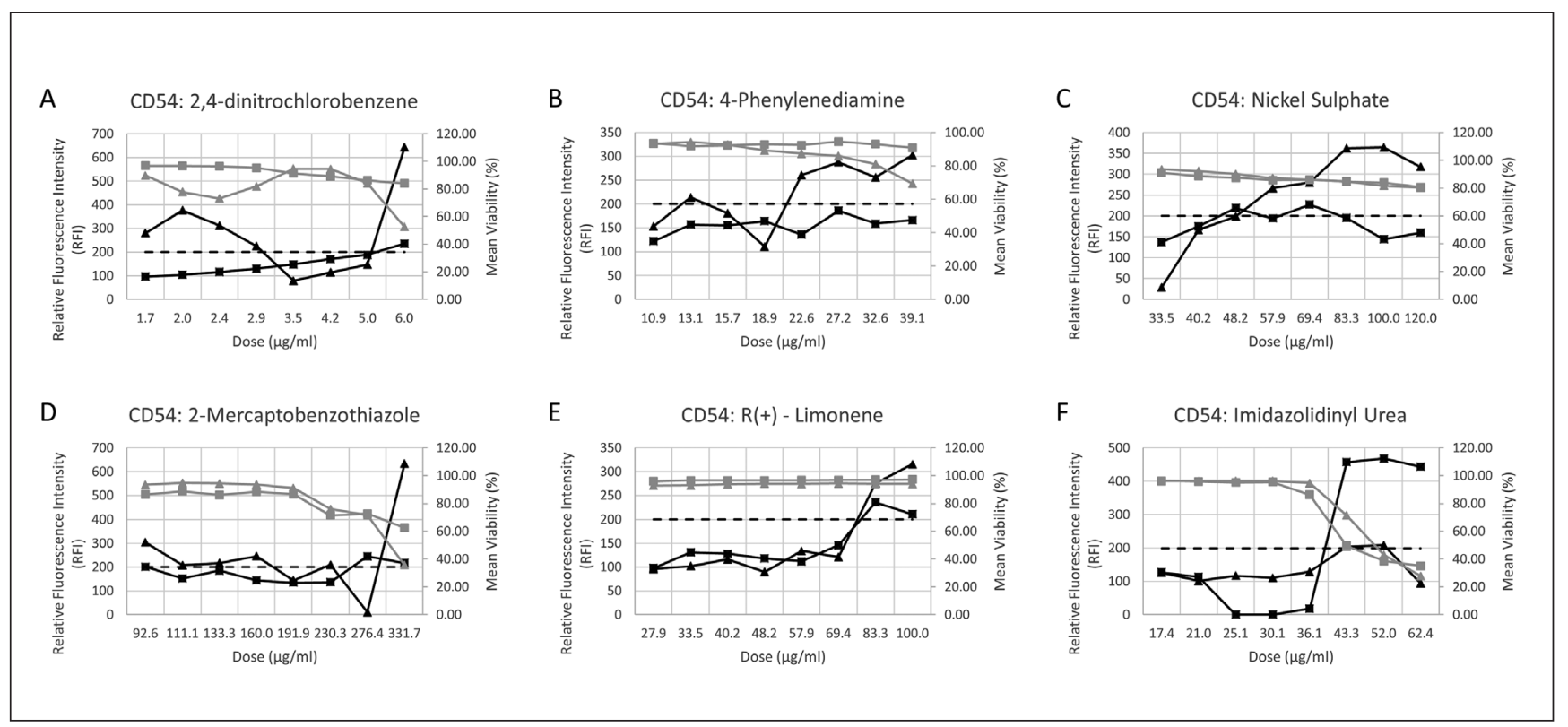

Fig. 2: CD54 RFI data for each proficiency substance considered to be a sensitizer (black lines) against concurrent cytotoxicity measurement (grey lines)

Triangular or square markers represent independent experiments $(n=2$ over an 8 -dose range). The dashed line represents the RFI threshold ( $R F I \geq 200$ ), which separates a sensitization effect from a non-sensitization effect. A, 2,4-dinitrochlorobenzene;

B, 4-phenylenediamine; C, nickel sulphate; D, 2-mercaptobenzothiazole; E, R(+)-limonene; F, imidazolidinyl urea.

\section{Results}

\subsection{THP-1 cell culture}

THP-1 cells cultured in animal-product-free conditions exhibited morphology and an average population doubling time of 44 hours $(\mathrm{n}=10$ independent experiments, range $35-53 \mathrm{~h}$ based upon mean \pm 3 standard deviations) that were consistent with the ATCC THP-1 data sheet and the details given in OECD TG 442E (mean $43 \mathrm{~h}$, range 30-55 h). Mean cell numbers after 48 hour and 72 hour pre-culture with initial seeding density at $0.2 \times 10^{6}$ cells/ $\mathrm{ml}$ were $0.41 \times 10^{6}$ and $0.61 \times 10^{6}$ cells $/ \mathrm{ml}$, respectively $(\mathrm{n}=10 \mathrm{in}-$ dependent experiments). Based upon these results, THP-1 cells used in the animal-product-free h-CLAT were seeded at $0.2 \times 10^{6}$ cells $/ \mathrm{ml}$ for both 48 and 72 hour pre-incubations as there was a low likelihood of cell overgrowth $\left(>1 \times 10^{6}\right.$ cells $\left./ \mathrm{ml}\right)$ during this time period. We found, in contrast to the information provided in DB-ALM Protocol No. $158^{1}$ regarding propagation duration (30 passages) that cells in animal-product-free culture reached senescence at earlier passage numbers and therefore THP-1 cells were not used after 20 passages. 


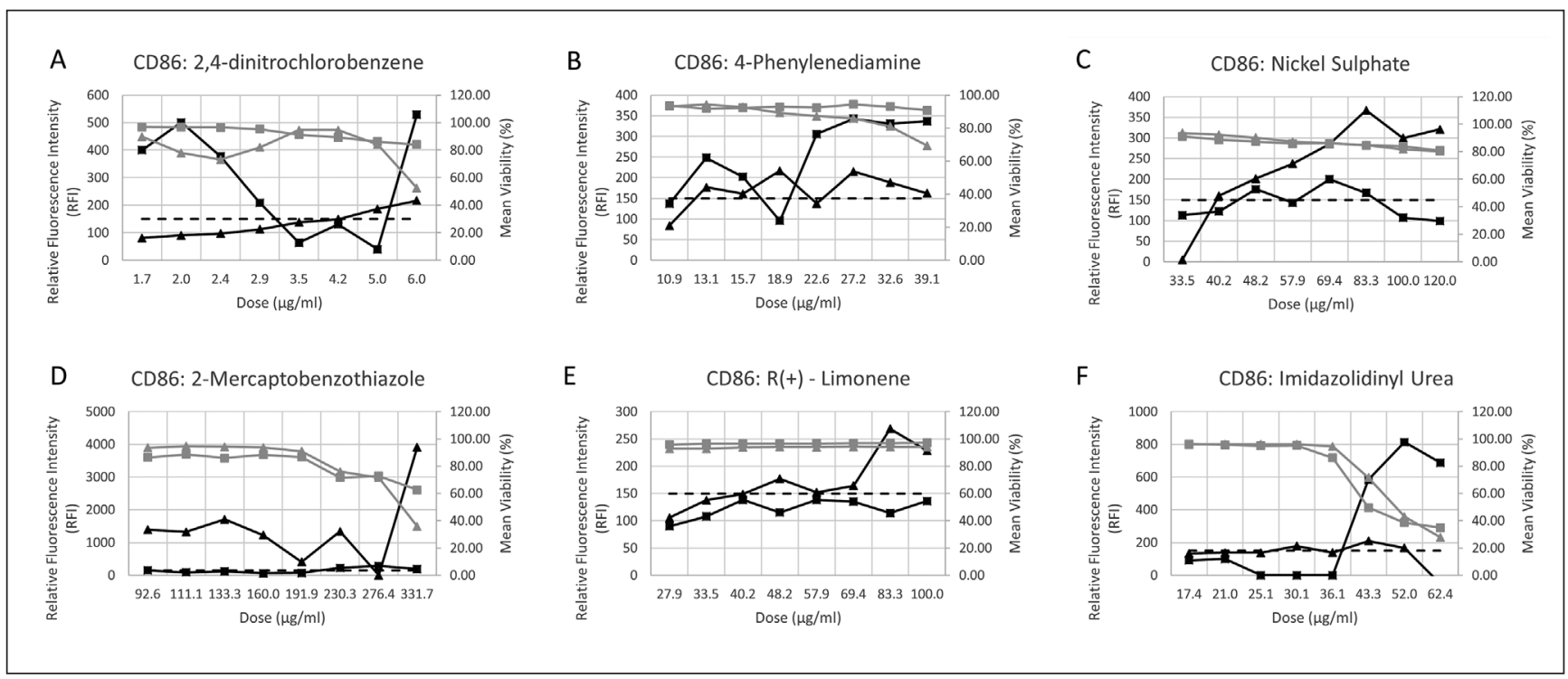

Fig. 3: CD86 RFI data for each proficiency substance considered to be a sensitizer (black lines) against concurrent cytotoxicity measurement (grey lines)

Triangular or square markers represent independent experiments $(n=2$ over an 8-dose range). The dashed line represents the RFI threshold (RFI $\geq 150$ ), which separates a sensitization effect from a non-sensitization effect. A, 2,4-dinitrochlorobenzene; B, 4-phenylenediamine; C, nickel sulphate; D, 2-mercaptobenzothiazole; E, R(+)-limonene; F, imidazolidinyl urea.

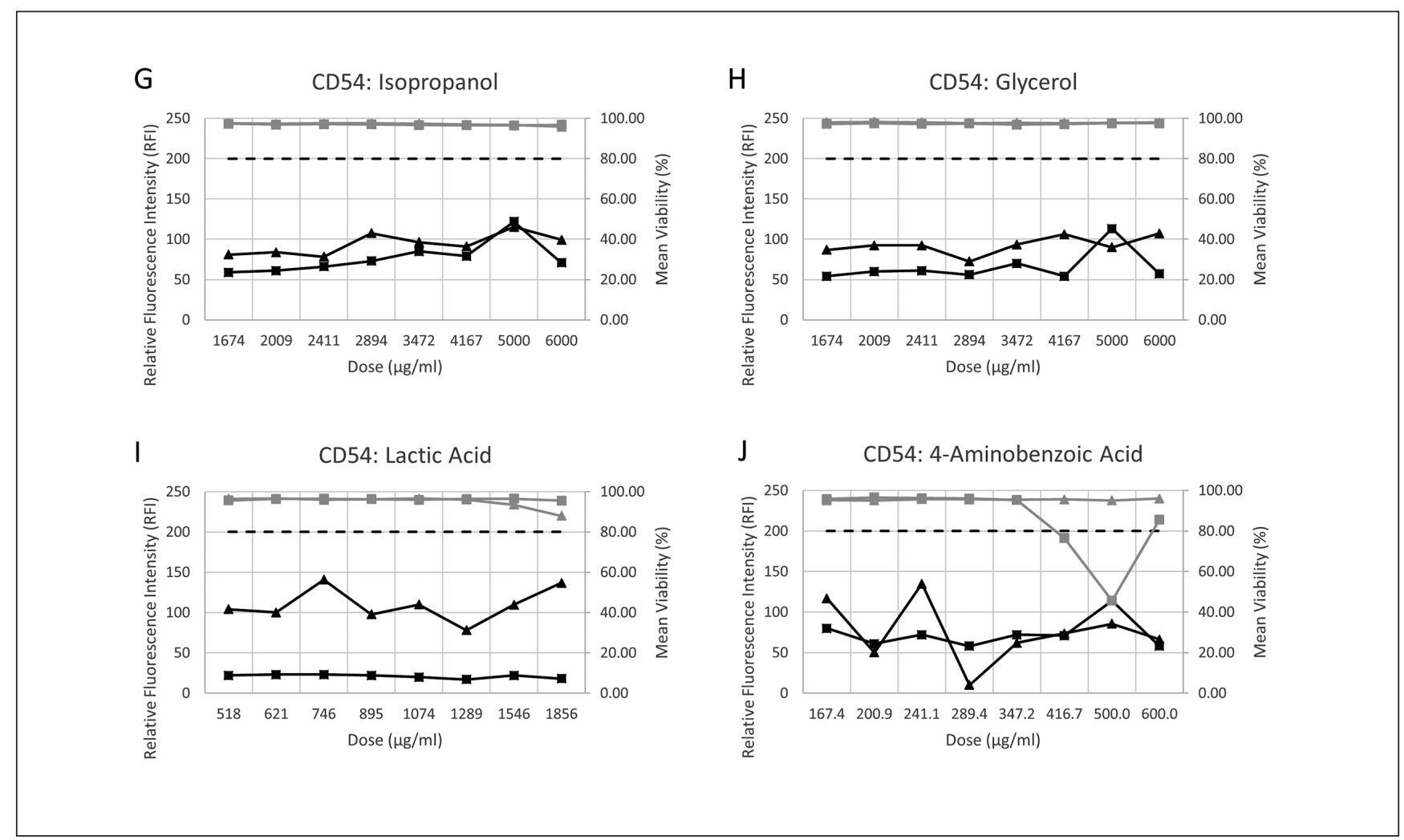

Fig. 4: CD54 RFI data for each proficiency substance considered to be a non-sensitizer (black lines) against concurrent cytotoxicity measurement (grey lines)

Triangular or square markers represent independent experiments ( $n=2$ over an 8-dose range). The dashed line represents the RFI threshold $(\mathrm{RFI} \geq 200$ ), which separates a sensitization effect from a non-sensitization effect. $\mathrm{G}$, isopropanol; $\mathrm{H}$, glycerol; I, lactic acid; J, 4-aminobenzoic acid. 
G

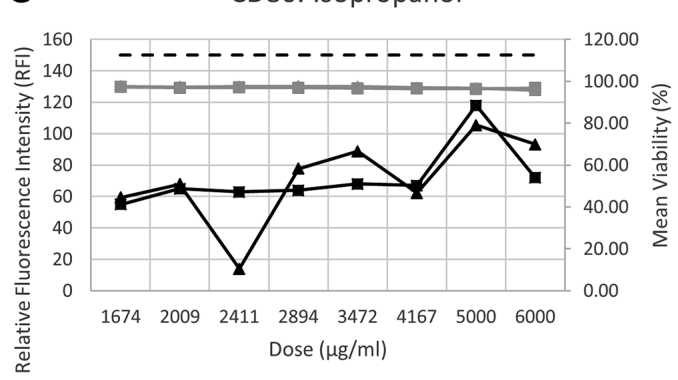

I

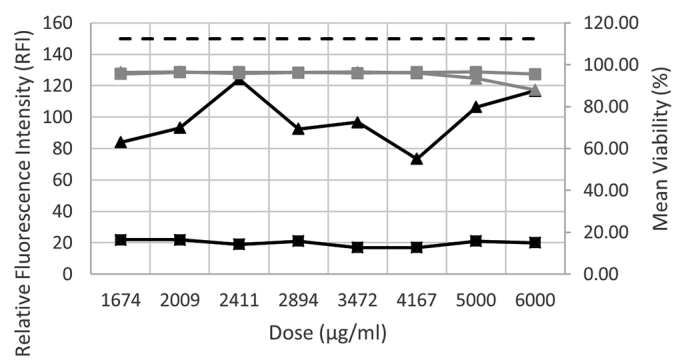

$\mathrm{H}$

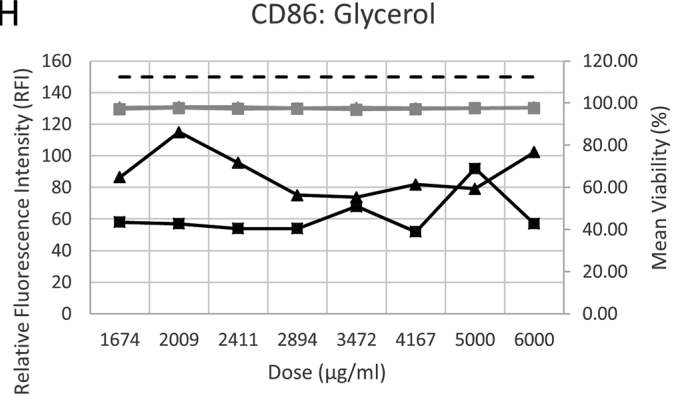

$\mathrm{J}$

CD86: 4-Aminobenzoic Acid

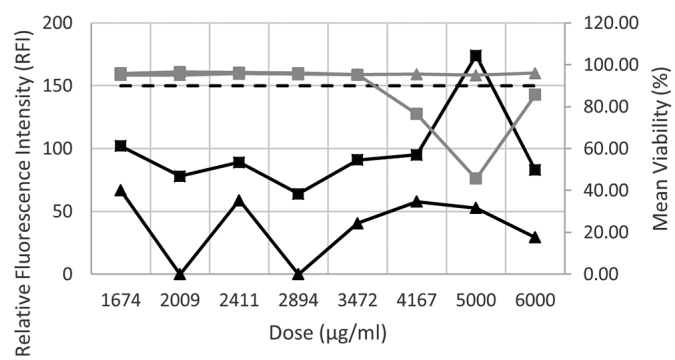

Fig. 5: CD86 RFI data for each proficiency substance considered to be a non-sensitizer (black lines) against concurrent cytotoxicity measurement (grey lines)

Triangular or square markers represent independent experiments ( $n=2$ over an 8-dose range). The dashed line represents the RFI threshold $(\mathrm{RFI} \geq 150)$, which separates a sensitization effect from a non-sensitization effect. $\mathrm{G}$, isopropanol; $\mathrm{H}$, glycerol; I, lactic acid; J, 4-aminobenzoic acid.

\subsection{Nickel sulphate positive control responses and THP-1 passage number}

Positive control data over 14 individual studies showed that nickel sulphate provided consistent results above the sensitization threshold at a range of THP-1 cell passage numbers for both CD54 and CD86 (Fig. 1). There was little correlation between increasing passage number and the RFI values of the responses as shown by the $\mathrm{r}^{2}$ values for CD54 and $86\left(\mathrm{r}^{2}=0.0076\right.$ and 0.2786 , respectively).

\section{3 h-CLAT}

The adapted animal-product-free version of the h-CLAT was used to test the 10 proficiency panel substances from OECD TG $442 \mathrm{E}$ that are detailed in Section 2.1.

\section{Dose finding CV75 values}

The dose of each proficiency substance that yielded 75\% THP-1 cell viability (CV75) is summarized in Table 2. All but one of the proficiency substances were within the reference range. Imidazolidinyl urea gave an average CV75 of $14.2 \mu \mathrm{g} / \mathrm{ml}$, which was marginally lower than the reference range (lower limit $25 \mu \mathrm{g} / \mathrm{ml}$ ), however, the test guideline specifies that the reference ranges should be met for 8 out of 10 substances and therefore the acceptance criterion was met.

\section{CD54 and CD86 expression measurement}

Figure 2 and 3 show representative examples of the CD54 and CD86 data produced for each of the 6 substances that are known sensitizers using the h-CLAT method as specified in the OECD guideline.

Figure 4 and 5 show representative examples of the CD54 and CD86 data produced for each of the 4 substances that are known non-sensitizers using the h-CLAT method as specified in the OECD guideline.

For each proficiency substance the EC200 and EC150 were calculated (Tab. 3). The results show that all 10 proficiency substances were correctly classified and were in the correct effective concentration (EC) ranges for 8 out of 10 substances as specified in OECD TG 442E, therefore, overall the acceptance criterion was passed and the animal-product-free adaptation of the assay was considered equivalent to the VRM detailed in OECD TG $442 \mathrm{E}$. Note that the two substances that did not meet the OECD EC ranges (lactic acid and 4-aminobenzoic acid) were correctly classified but due to the top doses used it was not possible to meet the specified EC ranges. Due to the experimental CV75 derived $(1546.4 \mu \mathrm{g} / \mathrm{ml})$, the highest dose tested for lactic acid was $1856 \mu \mathrm{g} / \mathrm{ml}$ and due to solubility limitations, the highest dose tested for 4-aminobenzoic acid was $600 \mu \mathrm{g} / \mathrm{ml}$. 
Tab. 3: EC200 (CD54) and EC150 (CD86) values (effective concentration, $\mu \mathrm{g} / \mathrm{ml}$, at which the sensitization threshold is crossed) for each proficiency substance

Data shown are EC values derived from 2 independent concordant experiments.

\begin{tabular}{|c|c|c|c|c|c|c|c|}
\hline \multirow{2}{*}{$\begin{array}{l}\text { Proficiency substance } \\
\text { 2,4-Dinitrochlorobenzene }\end{array}$} & \multicolumn{2}{|c|}{$\begin{array}{l}\text { XCellR8 } \\
\text { EC200 }(\mu \mathrm{g} / \mathrm{ml})\end{array}$} & \multicolumn{2}{|c|}{$\begin{array}{l}\text { XCellR8 } \\
\text { EC150 }(\mu \mathrm{g} / \mathrm{ml})\end{array}$} & \multirow{2}{*}{$\begin{array}{l}\text { OECD EC200 } \\
\text { range }(\mu \mathrm{g} / \mathrm{ml})\end{array}$} & \multirow{2}{*}{$\begin{array}{l}\text { OECD EC150 } \\
\text { range }(\mu \mathrm{g} / \mathrm{ml})\end{array}$} & \multirow{2}{*}{$\begin{array}{l}\text { Meets OECD } \\
\text { TG 442E range } \\
\text { Yes }\end{array}$} \\
\hline & 1 & 5 & 1 & 4 & & & \\
\hline 4-Phenylenediamine & 13 & $\mathrm{Neg}$ & 11 & 12 & Neg or $>1.5$ & $<40$ & Yes \\
\hline Nickel sulphate & 48 & 45 & 40 & 44 & $10-100$ & $<100$ & Yes \\
\hline 2-Mercaptobenzothiazole & 103 & 89 & 63 & 93 & $10-140$ & Neg or $>10$ & Yes \\
\hline $\mathrm{R}(+)$-Limonene & 77 & 78 & Neg & 41 & $<250$ & Neg or $>5$ & Yes \\
\hline Imidazolidinyl urea & 36 & 39 & 35 & 40 & $20-75$ & $20-90$ & Yes \\
\hline Isopropanol & \multicolumn{2}{|c|}{$\operatorname{Neg}(>5000)$} & \multicolumn{2}{|c|}{$\operatorname{Neg}(>5000)$} & $\operatorname{Neg}(>5000)$ & $\operatorname{Neg}(>5000)$ & Yes \\
\hline Glycerol & \multicolumn{2}{|c|}{$\operatorname{Neg}(>5000)$} & \multicolumn{2}{|c|}{$\operatorname{Neg}(>5000)$} & Neg $(>5000)$ & $\operatorname{Neg}(>5000)$ & Yes \\
\hline Lactic acid & \multicolumn{2}{|c|}{$\operatorname{Neg}(>1856)$} & \multicolumn{2}{|c|}{$\operatorname{Neg}(>1856)$} & $\operatorname{Neg}(>5000)$ & $\operatorname{Neg}(>5000)$ & No* \\
\hline 4-Aminobenzoic acid & \multicolumn{2}{|c|}{$\operatorname{Neg}(>600)$} & \multicolumn{2}{|c|}{$\operatorname{Neg}(>600)$} & $\operatorname{Neg}(>1000)$ & $\operatorname{Neg}(>1000)$ & $\mathrm{No}^{* *}$ \\
\hline
\end{tabular}

*Due to the experimental CV75 derived $(1546.4 \mu \mathrm{g} / \mathrm{ml})$, the highest dose tested for lactic acid was $1856 \mu \mathrm{g} / \mathrm{ml}$.

${ }^{\star *}$ Due to solubility limitations, the highest dose tested for 4-aminobenzoic acid was $600 \mu \mathrm{g} / \mathrm{ml}$.

Comparison of multiple lots of human serum

CV75 values as well as CD54 and CD86 expression were assessed for THP-1 cells cultured and tested using three separate lots of human serum. Six proficiency chemicals, which were selected through consultation with the OECD Expert Working Group on Skin Sensitisation, i.e. 2,4-dinitrochlorobenzene, 4-phenylenediamine, nickel sulphate, isopropanol, glycerol and lactic acid were tested in duplicate runs using two additional lots of human serum in addition to the data previously generated with human serum lot 1 . All CV75 ranges were met for all proficiency chemicals using the three lots of human serum (Tab. 4).

Top doses and hence the dilution ranges for CD54 and CD86 expression measurement for 2,4-dinitrochlorobenzene and nickel sulphate were based upon historical in-house reactivity check data $(6 \mu \mathrm{g} / \mathrm{ml}$ and $120 \mu \mathrm{g} / \mathrm{ml}$ top doses, respectively) rather than the experimental CV75 values generated, however, it is worth noting that these dosing ranges did include values both above and below the experimentally derived CV75 values. All test items were subsequently correctly classified as positive (Fig. 6, 7,8 ) or negative (data not shown) as per OECD TG 442E across the three lots of human serum.

In addition, all test chemicals met the acceptance ranges for EC150 and EC200 values with the exception of lactic acid, which did not meet the OECD range due to the experimental CV75 values (Tab. 5, 6).

\section{Discussion}

An integrated approach to in chemico and in vitro skin sensitization using three methods, DPRA, KeratinoSens ${ }^{\mathrm{TM}}$ and h-CLAT, has recently been approved by the OECD, marking an important milestone in the replacement of animal tests. These in chemico and in vitro test methods have gained full regulatory acceptance and have been incorporated into the REACH regulation in Europe as the testing strategy of choice for the skin sensitization endpoint. The methods cover three key events of the skin sensitization pathway; KE 1 - assessment of skin protein binding (DPRA, OECD TG 442C; OECD, 2015), KE 2 - measuring keratinocyte activation (KeratinoSens ${ }^{\mathrm{TM}}$, OECD TG 442D; OECD, 2018a) and KE 3 - assessment of dendritic cell activation (h-CLAT, OECD TG 442E; OECD, 2018b). The traditional animal-based method for the assessment of skin sensitization, OECD TG 429 - the Local Lymph Node Assay (LLNA) (OECD, 2010), may now only be used as a last resort for hazard identification and labelling purposes. While the LLNA is sometimes still required for potency prediction, these developments represent a significant shift towards the adoption of in vitro technologies in the context of regulatory safety testing.

It is however important to acknowledge that although significant progress has been made, many in vitro methods currently use animal-derived components such as fetal calf serum, mouse or rabbit antibodies, porcine trypsin and rat liver extracts. In addition, animal-derived cell lines are widely used in models for human endpoints. As such, these methods still ultimately require the sacrifice of animals and cannot be considered completely animal-product-free. Use of animal components also presents scientific limitations by unnecessarily compromising the direct relevance of the test system to humans.

The significant animal welfare concerns around the production of certain animal-derived components have also been well documented (Jochems et al., 2002; Even et al., 2006; van der Valk et al., 2018). Importantly, these scientific and ethical drawbacks give rise to concerns within the cosmetics and personal care industry. The European Cosmetics Regulation 1223/2009 includes an animal testing ban for cosmetic products and in- 


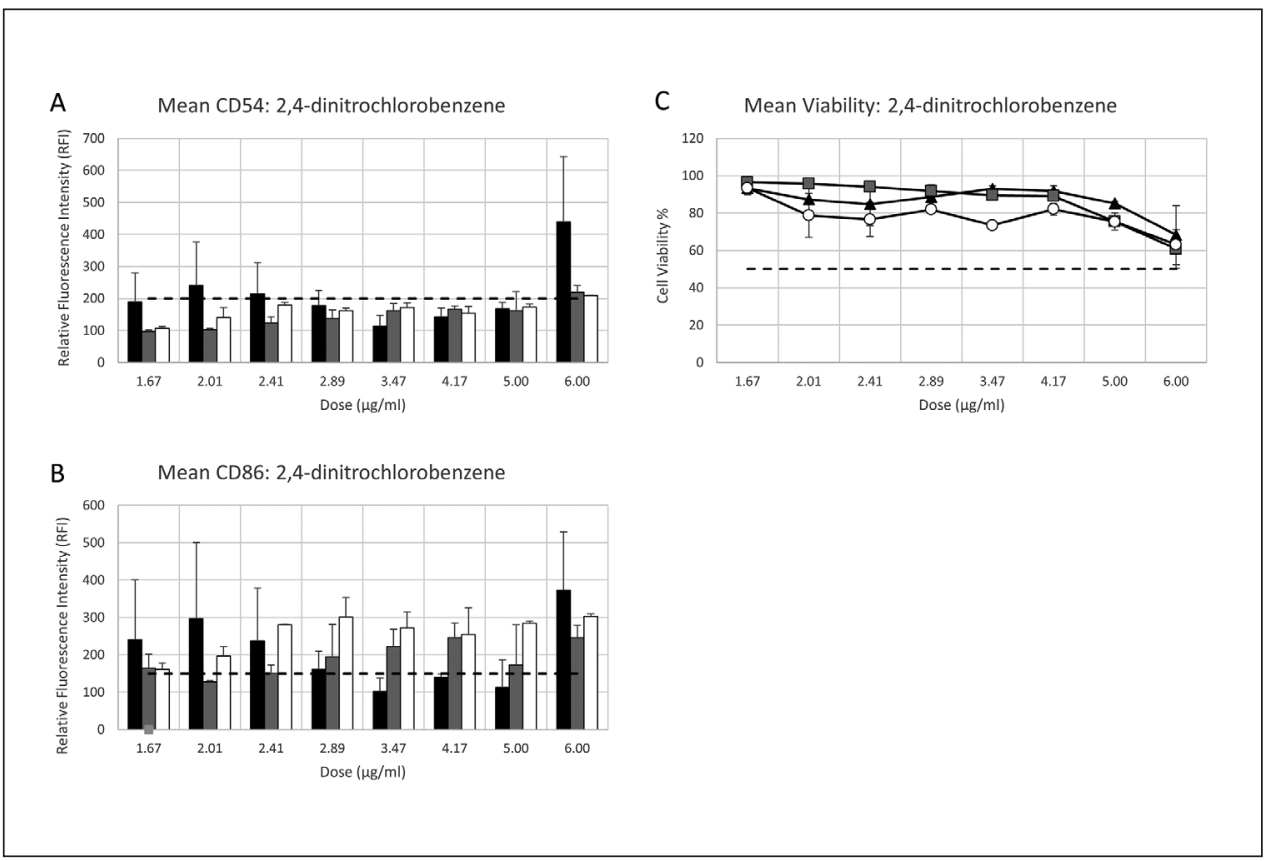

Fig. 6: RFI data for CD54 (A) and CD86 (B) for

\section{2,4-dinitrochlorobenzene} generated using 3 separate lots of human serum ( $n=6$ over an 8-dose range) with concurrent cytotoxicity measurement (C)

For the RFI graphs (A) and (B) the black bars represent human serum lot 1 , the grey bars represent human serum lot 2 , and the white bars represent human serum lot 3 . For the cytotoxicity graph $(\mathrm{C})$, the black triangles represent human serum lot 1 , the grey squares represent human serum lot 2 , and the white circles represent human serum lot 3. The data presented are mean and SEM values from two individual experiments for each lot of human serum $(n=6$ in total).

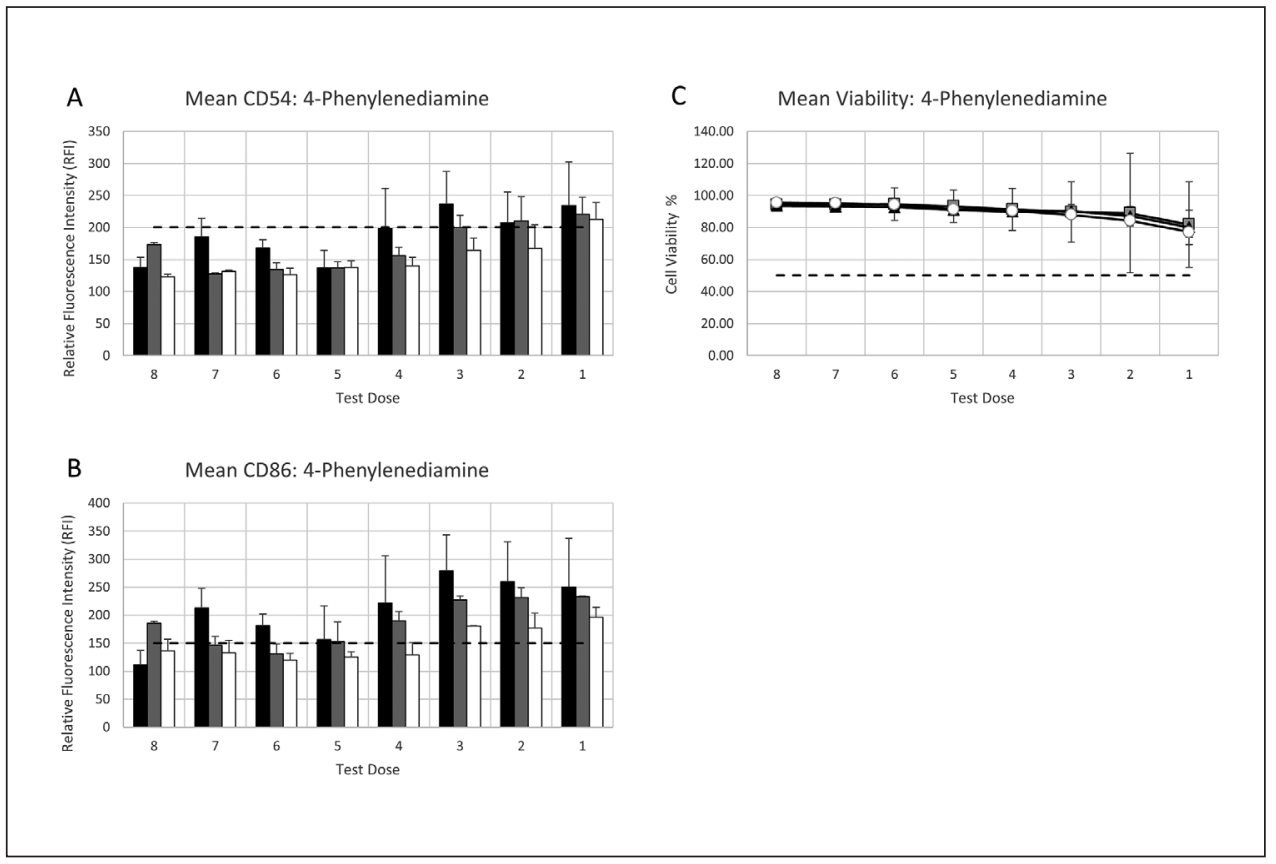

Fig. 7: RFI data for CD54 (A) and CD86 (B) for

4-phenylenediamine generated using 3 separate lots of human serum ( $n=6$ over an 8-dose range) with concurrent cytotoxicity measurement (C) For the RFI graphs (A) and (B) the black bars represent human serum lot 1 , the grey bars represent human serum lot 2 , and the white bars represent human serum lot 3 . For the cytotoxicity graph $(\mathrm{C})$, the black triangles represent human serum lot 1 , the grey squares represent human serum lot 2 , and the white circles represent human serum lot 3. The data presented are mean and SEM values from two individual experiments for each lot of human serum $(n=6$ in total). The test doses used for 4-phenylenediamine were based around 1.2-fold dilutions above and below the experimental CV75 (Test dose 2) and were as follows for each of the lots of human serum: Lot1 CV75 $=32.6$, Lot 2 CV75 $=23.6$ and Lot 3 CV75 $=14.7 \mu \mathrm{g} / \mathrm{ml}$. 


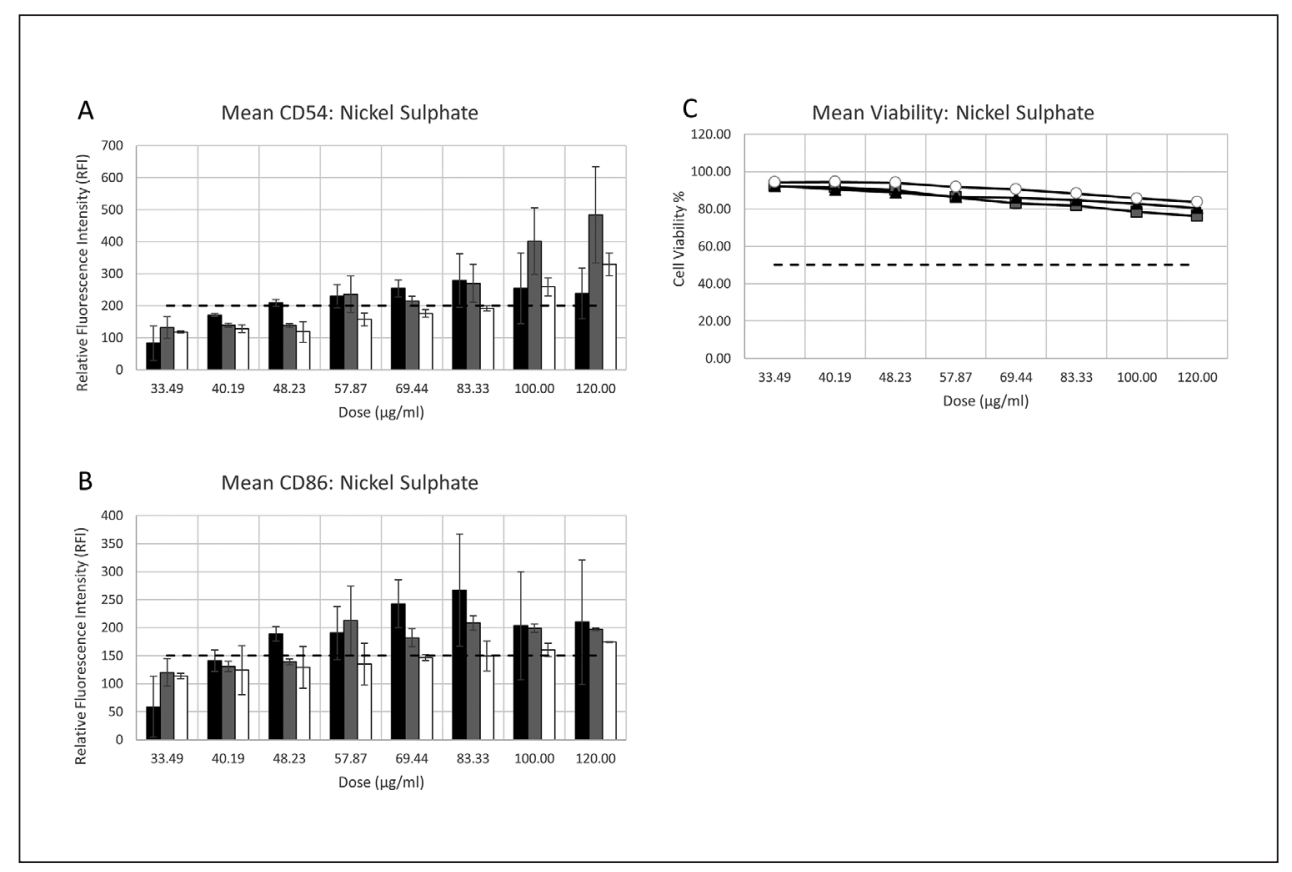

Fig. 8: RFI data for CD54 (A) and CD86 (B) for nickel sulphate generated using 3 separate lots of human serum ( $n=6$ over an 8 -dose range) with concurrent cytotoxicity measurement (C) For the RFI graphs (A) and (B) the black bars represent human serum lot 1 , the grey bars represent human serum lot 2 , and the white bars represent human serum lot 3 . For the cytotoxicity graph (C), the black triangles represent human serum lot 1 , the grey squares represent human serum lot 2, and the white circles represent human serum lot 3. The data presented are mean and SEM values from two individual experiments for each lot of human serum ( $n=6$ in total).

Tab. 4: CV75 values (dose yielding $75 \%$ cell viability, $\mu \mathrm{g} / \mathrm{ml}$ )

Values derived from 2 independent experiments for 3 independent lots of human serum compared against the reference range from OECD TG 442E.

\begin{tabular}{|l|l|l|l|l|}
\hline Proficiency substance & OECD range & $\begin{array}{l}\text { Human serum lot 1 } \\
\mathbf{C V 7 5} \text { average }(\boldsymbol{\mu g} / \mathrm{ml})\end{array}$ & $\begin{array}{l}\text { Human serum lot 2 } \\
\mathbf{C V 7 5} \text { average }(\boldsymbol{\mu g} / \mathrm{ml})\end{array}$ & $\begin{array}{l}\text { Human serum lot 3 } \\
\mathbf{C V 7 5} \text { average }(\boldsymbol{\mu g} / \mathrm{ml})\end{array}$ \\
\hline 2,4-Dinitrochlorobenzene & $2-12$ & 3.20 & 3.2 & 2.40 \\
\hline 4-Phenylenediamine & $5-95$ & 32.60 & 23.6 & 14.70 \\
\hline Nickel sulphate & $30-500$ & 44.40 & 92.5 & 90.30 \\
\hline Isopropanol & $>5000$ & 5000 & 5000 & 5000 \\
\hline Glycerol & $>5000$ & 5000 & 5000 & 5000 \\
\hline Lactic acid & $1500-5000$ & 1546.40 & 2852.6 & 2053.40 \\
\hline
\end{tabular}

gredients. Globally, animal testing is a highly emotive issue in many countries and there is increasing demand from consumers for "cruelty-free" cosmetic products, in which neither the final formulation nor individual ingredients have been tested on animals. Many ethical cosmetic companies seek to go beyond the "bare minimum" expectation, and to satisfy consumer demand by avoiding the use of animal-derived components altogether. In response to this demand, new methods developed at XCellR8 are animal-product-free from the outset, and the organization openly encourages other laboratories to adopt the same approach, avoiding the need for adaptation after the formal process of validation and regulatory acceptance has been completed. In addition, we have been asked by leading cosmetic companies to adapt existing regulatory methods to animal-product-free conditions, and to seek regulatory acceptance for the updated protocols. In many cases, human equivalents for traditionally used animal products are readily available, e.g., in the case of cell lines or the use of serum. Recently, the KeratinoSens ${ }^{\mathrm{TM}}$ animal-product-free adaptation developed at XCellR8 (Belot et al., 2017) has been approved for inclusion into OECD TG 442D.

The h-CLAT method for skin sensitization (OECD TG 442E) was adapted to animal-product-free conditions and further optimized by making further minor adaptations to the established protocol (Tab. 7).

The THP-1 cell line adapted well to routine culture in medium containing $10 \%$ human serum instead of bovine serum, exhibiting normal morphology and comparable doubling times (Section 3.1). Following adaptation to human serum, a cell bank of THP-1 cells was created for long term use. Cells were successfully used after thawing from long term liquid nitrogen storage. The THP-1 cell seeding density for pre-culture was found to be optimal at $0.2 \times 10^{6}$ cells $/ \mathrm{ml}$ in animal-product-free conditions 
Tab. 5: Classification and EC200 values (CD54) generated using three separate lots of human serum ( $n=6$ over an 8-dose range) for six proficiency chemicals

Data shows that all classifications are correct and that all EC200 values with the exception of lactic acid have met the required range as described in OECD TG 442E.

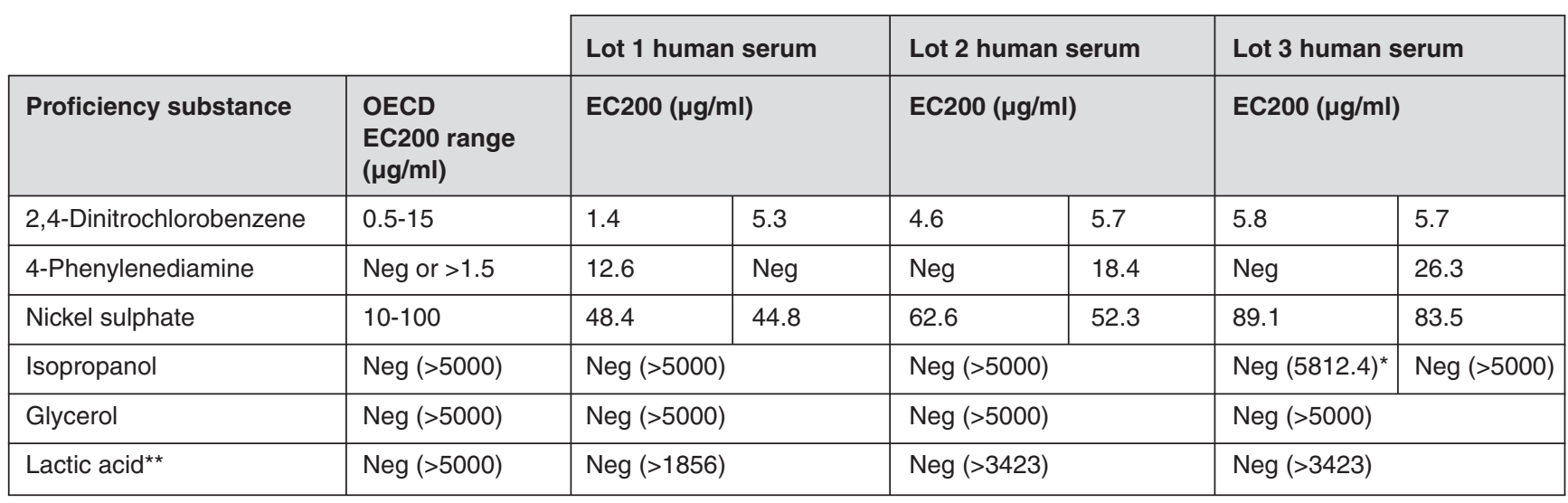

*Note that Isopropanol in this replicate tested positive at the top concentration used $(6000 \mu \mathrm{g} / \mathrm{ml})$; however, this is above the usual specified range for the test method and was tested in this way so that actual data above $5000 \mu \mathrm{g} / \mathrm{ml}$ could be generated rather than being obtained by extrapolation. The EC200 derived was also above $5000 \mu \mathrm{g} / \mathrm{ml}$ as specified in TG 442E. Therefore, this result was deemed acceptable and considered as negative overall for the chemical.

**Lactic acid CV75 values were $<5000 \mu \mathrm{g} / \mathrm{ml}$ and although all results were negative, the OECD range was not met due to the CV75 values obtained - it is suggested that the EC200 range should be expanded in TG $442 \mathrm{E}$ to be $1500-5000 \mu \mathrm{g} / \mathrm{ml}$ in order to allow all possible CV75 values for this proficiency chemical.

Tab. 6: Classification and EC150 values (CD86) generated using three separate lots of human serum ( $n=6$ over an 8-dose range) for six proficiency chemicals

Data shows that all classifications are correct and that all EC150 values with the exception of lactic acid have met the required range as described in OECD TG 442E.

\begin{tabular}{|c|c|c|c|c|c|c|c|}
\hline \multirow{3}{*}{$\begin{array}{l}\text { Proficiency substance } \\
\text { 2,4-Dinitrochlorobenzene }\end{array}$} & \multirow{3}{*}{$\begin{array}{l}\text { OECD } \\
\text { EC150 range } \\
(\mu \mathrm{g} / \mathrm{ml}) \\
0.5-10\end{array}$} & \multirow{2}{*}{\multicolumn{2}{|c|}{$\begin{array}{l}\text { Lot } 1 \text { human serum } \\
\text { EC150 }(\mu \mathrm{g} / \mathrm{ml})\end{array}$}} & \multirow{2}{*}{\multicolumn{2}{|c|}{$\begin{array}{l}\text { Lot } 2 \text { human serum } \\
\text { EC150 }(\mu \mathrm{g} / \mathrm{ml})\end{array}$}} & \multirow{2}{*}{\multicolumn{2}{|c|}{$\begin{array}{l}\text { Lot } 3 \text { human serum } \\
\text { EC150 }(\mu \mathrm{g} / \mathrm{ml})\end{array}$}} \\
\hline & & & & & & & \\
\hline & & 1.1 & 4.2 & 2.2 & 3.3 & 1.5 & 1.7 \\
\hline 4-Phenylenediamine & $<40$ & 11.2 & 12.5 & 11.5 & 15.3 & 16.2 & 18.3 \\
\hline Nickel sulphate & $<100$ & 39.8 & 44.3 & 56.3 & 49.3 & 69 & 37.7 \\
\hline Isopropanol & Neg $(>5000)$ & \multicolumn{2}{|c|}{$\operatorname{Neg}(>5000)$} & \multicolumn{2}{|c|}{$\operatorname{Neg}(>5000)$} & \multicolumn{2}{|c|}{$\operatorname{Neg}(>5000)$} \\
\hline Glycerol & $\operatorname{Neg}(>5000)$ & \multicolumn{2}{|c|}{$\operatorname{Neg}(>5000)$} & \multicolumn{2}{|c|}{$\operatorname{Neg}(>5000)$} & \multicolumn{2}{|c|}{ Neg $(>5000)$} \\
\hline Lactic acid* & $\operatorname{Neg}(>5000)$ & \multicolumn{2}{|c|}{ Neg $(>1856)$} & \multicolumn{2}{|c|}{$\operatorname{Neg}(>3423)$} & \multicolumn{2}{|c|}{ Neg (>3423) } \\
\hline
\end{tabular}

*Lactic acid CV75 values were $<5000 \mu \mathrm{g} / \mathrm{ml}$ and although all results were negative, the OECD range was not met due to the CV75 values obtained - it is suggested that the EC150 range should be expanded in TG $442 \mathrm{E}$ to be $1500-5000 \mu \mathrm{g} / \mathrm{ml}$ in order to allow all possible CV75 values for this proficiency chemical.

regardless of the pre-culture period (48 or $72 \mathrm{~h}$ ) as the cells did not overgrow during this time.

The changes to the staining buffer (HSA instead of BSA) did not affect the wash steps for the cells or affect the PI or antibody staining as observed in routine use and shown by the overall final results.

Prior to receipt of the antibodies, an initial assessment of antigen affinity using $\mathrm{K}_{\mathrm{OFF}}$ ranking (rate constant for dissociation of antibodies from target antigen) and QC ELISA for assessment of the target antigen signal was carried out by BioRad. Use of the custom HuCAL antibodies in the assay was initially optimized through the use of the reactivity check chemicals (DNCB, $\mathrm{NiSO}_{4}$ and lactic acid) to obtain consistent equivalent performance to the standard TG antibodies. The antibodies were then validated as suggested in OECD TG 442E by testing the proficiency substances listed in Annex II. All proficiency substances were correctly classified, demonstrating equivalent results to those obtained with the mouse-derived antibodies as detailed in the test guideline. 
Tab. 7: Adaptation to animal-product-free conditions and further optimization of the h-CLAT method for skin sensitization (OECD TG 442E)

\begin{tabular}{|c|c|c|c|}
\hline $\begin{array}{l}\text { Section in } \\
\text { OECD } \\
\text { TG } 442 E \\
\text { (v. } 29 \text { Jul 16) }\end{array}$ & $\begin{array}{l}\text { Validated reference } \\
\text { method (VRM) }\end{array}$ & XCellR8 adaptation & Comments \\
\hline $\begin{array}{l}\text { Page 4, } \\
\text { section } 18\end{array}$ & $\begin{array}{l}10 \% \text { foetal bovine serum for } \\
\text { THP- } 1 \text { cell culture }\end{array}$ & $10 \%$ human serum & Animal-product-free adaptation \\
\hline $\begin{array}{l}\text { Page 5, } \\
\text { section } 19\end{array}$ & $\begin{array}{l}\text { THP-1 cells are seeded at } \\
\text { a density of either } 0.1 \times 10^{6} \\
\text { or } 0.2 \times 10^{6} \text { cells } / \mathrm{ml} \text { and pre- } \\
\text { cultured for } 72 \mathrm{hrs} \text { or } 48 \mathrm{hrs} \\
\text { respectively }\end{array}$ & $\begin{array}{l}\text { THP- } 1 \text { cells are seeded at a } \\
\text { density of } 0.2 \times 10^{6} \text { cells } / \mathrm{ml} \\
\text { and pre-cultured for } 48 \mathrm{hrs} \text { or } \\
72 \text { hrs. }\end{array}$ & $\begin{array}{l}\text { Optimisation, not a true adaptation. We found that } \\
\text { cells do not overgrow when seeded at } 0.2 \times 10^{6} \text { cells/ } \\
\text { ml and pre-cultured for either } 48 \text { or } 72 \text { hrs in animal- } \\
\text { product-free conditions. }\end{array}$ \\
\hline $\begin{array}{l}\text { Page } 6, \\
\text { section } 25\end{array}$ & $\begin{array}{l}\text { Staining buffer is phosphate } \\
\text { buffered saline containing } \\
0.1 \% \text { bovine serum albumin }\end{array}$ & $\begin{array}{l}\text { Staining buffer is phosphate } \\
\text { buffered saline containing } \\
0.1 \% \text { human serum albumin }\end{array}$ & Animal-product-free adaptation \\
\hline $\begin{array}{l}\text { Page } 7 \\
\text { section } 28\end{array}$ & $\begin{array}{l}\text { DNCB used as the positive } \\
\text { control for CD54/CD86 } \\
\text { expression }\end{array}$ & $\begin{array}{l}\text { DNCB used as the positive } \\
\text { control for CV75 assay. Nickel } \\
\text { sulphate used as the positive } \\
\text { control for CD54/CD86 } \\
\text { expression. }\end{array}$ & $\begin{array}{l}\text { Optimisation, not a true adaptation. Nickel sulphate } \\
\text { provided more robust responses in the animal-product- } \\
\text { free system. TG } 442 E \text { allows for change of the positive } \\
\text { control: "Other suitable positive controls may be used } \\
\text { if historical data are available to derive comparable } \\
\text { run acceptance criteria". Nickel sulphate is one of the } \\
\text { reactivity check chemicals used in the test guideline } \\
\text { and therefore is a well-established control. }\end{array}$ \\
\hline $\begin{array}{l}\text { Page } 8 \\
\text { section } 31\end{array}$ & $\begin{array}{l}\text { Mouse anti-CD54, anti-CD86 } \\
\text { and IgG1 (Isotype) antibodies } \\
\text { used }\end{array}$ & $\begin{array}{l}\text { Custom HuCAL anti-CD54, } \\
\text { anti-CD } 86 \text { and negative } \\
\text { control (Isotype) made by } \\
\text { phage display from human } \\
\text { source. }\end{array}$ & $\begin{array}{l}\text { TG } 442 E \text { allows for adaptation of the antibodies in } \\
\text { the text: "Other fluorochrome-tagged anti-CD } 86 \text { and/ } \\
\text { or anti-CD54 antibodies may be used if they can be } \\
\text { shown to provide similar results as FITC-conjugated } \\
\text { antibodies, for example by testing the proficiency } \\
\text { substances in Annex II." Consistent performance } \\
\text { observed between } 4 \text { lots used in development and in } \\
\text { subsequent use (data not shown). }\end{array}$ \\
\hline
\end{tabular}

The animal-product-free adaptations were validated through the testing of the 10 proficiency substances. The CV75 ranges were met for 9 out of 10 of the substances, which passed the acceptance criterion for this assay. It is worth noting that imidazolidinyl urea gave an average CV75 of $14.2 \mu \mathrm{g} / \mathrm{ml}$, which was only marginally lower than the reference range $(25-100 \mu \mathrm{g} / \mathrm{ml})$. In terms of the CD54 and CD86 expression, all proficiency substances were correctly classified as either positive or negative. The EC200 and EC150 ranges were met for 8 out of 10 of the substances that passed the acceptance criterion stipulated in the guideline. It is worth noting that due to the experimental CV75 derived $(1546.4 \mu \mathrm{g} / \mathrm{ml})$, the highest dose tested for lactic acid was $1856 \mu \mathrm{g} / \mathrm{ml}$ and therefore this substance could not meet the EC ranges specified ( $>5000)$, although it was correctly classified as negative. It is suggested that the EC150 and EC200 ranges should be expanded in TG 442E to be $1500-5000 \mu \mathrm{g} / \mathrm{ml}$ in order to allow all possible valid CV75 values for lactic acid. Due to solubility limitations, the highest dose tested for 4-aminobenzoic acid was $600 \mu \mathrm{g} / \mathrm{ml}$ and therefore this substance did not meet the EC ranges specified ( $>1000)$, although it was correctly classified as negative.

In addition, comparison of CV75 and CD54 and CD86 expression values across 3 lots of human serum ( 2 independent runs per lot of human serum) showed that there was no difference between different lots of human serum in terms of meeting the acceptance criteria as described in OECD TG 442E. Use of three lots of human serum represents a large number of pooled donors (in the range of 150-210 donors overall across the 3 lots) and demonstrates good repeatability between lots.

The adapted method provides benefits from both a scientific and ethical perspective. From a scientific perspective, the elimination of animal-derived components from in vitro test systems and replacement with human equivalents directly increases the relevance of the test system as a model of human biology. From an ethical perspective, the adaptations also provide cosmetic companies with an in vitro system that can respond to consumer demands to replace the use of animals and animal-derived components altogether in cosmetics testing.

For the future, fully defined cell culture conditions are under consideration - an approach with wide support due to the potential for enhanced reproducibility. However, the development of fully defined systems for many cell types is a costly and time-consuming process and cannot address the immediate need for animal-product-free testing solutions for the ethically-focused cosmetics sector. While defined media are desirable for many applications, for regulatory testing the use of human reagents, especially human serum from a large pool of donors, may be more closely aligned to a "real-life" response to chemicals and therefore fully appropriate for safety assessment purposes.

The human serum used in the animal-product-free culture systems is from pooled donors (approximately 50-70 pooled donors 
per lot). As with any type of serum, when a new lot is used, an internal validation of the lot including assessment of cell morphology, growth rates and positive control performance in the relevant assay should be conducted in order to ensure consistent performance. Human equivalents to animal-derived cell culture components are freely available commercially and should be sourced from reputable suppliers with full donor consent and safety screening. In our experience, differences in the cost of such products compared with the animal-derived equivalents are minimal and do not have an impact on the overall cost associated with performing the test.

The animal-product-free adaptation to the h-CLAT method, described here, will further contribute to international harmonization of hazard identification and risk assessment. Regulatory acceptance would enable incorporation into the skin sensitization IATA (Integrated Approach to Testing and Assessment) as a completely animal-product-free in vitro test option alongside the adapted KeratinoSens ${ }^{\mathrm{TM}}$ method that we recently published, which has been accepted by the OECD for inclusion into TG 442D. This is a novel development as it is the first time a battery of completely animal-product-free methods is available for testing a specific endpoint as part of an IATA. We have obtained clarification from the European Chemicals Agency (ECHA) that data generated using the adapted method may be used in $\mathrm{REACH}$ submissions, provided that the performance substance data, demonstrating equivalence with the standard method described in OECD TG 442E, is included in the dossier. We are currently pursuing inclusion of the adapted method into OECD TG 442E. Formal listing in the TG would mean that the proposed adaptation to the existing method would be globally available for use by test laboratories for compliance with a range of chemical safety regulations around the world. Subsequent adoption by other laboratories will collectively avoid the unnecessary use of a large volume of animal-derived serum in the future, while maximizing the relevance of the test to human safety.

\section{References}

Ashikaga, T., Yoshida, Y., Hirota, M. et al. (2006). Development of an in vitro skin sensitization test using human cell lines: The human cell line activation test (h-CLAT) I. Optimization of the h-CLAT protocol. Toxicol In Vitro 20, 767-773. doi:10.1016/j. tiv.2005.10.012

Belot, N., Sim, B., Longmore, C. L. et al. (2017). Adaptation of the KeratinoSens ${ }^{\mathrm{TM}}$ skin sensitisation test to animal-product-free cell culture. ALTEX 34, 560-564. doi:10.14573/altex.1701311

EURL ECVAM (2012). human Cell Line Activation Test (h-CLAT) Validation Study Report. https://eurl-ecvam.jrc.ec.europa.eu/ eurl-ecvam-recommendations

Even, M. S., Sandusky, C. B. and Barnard, N. D. (2006). Serum-free hybridoma culture: Ethical, scientific and safety considerations. Trends Biotechnol 24, 105-108. doi:10.1016/j. tibtech.2006.01.001

Gerberick, G. F., Vassallo, J. D., Bailey, R. E. et al. (2004). Development of a peptide reactivity assay for screening contact allergens. Toxicol Sci 81, 332-343. doi:10.1093/toxsci/kfh213
Jochems, C. E., van der Valk, J. B., Stafleu, F. R. and Baumans, V. (2002). The use of fetal bovine serum: Ethical or scientific problem? Altern Lab Anim 30, 219-227.

Knappik, A., Ge, L., Honegger, A. et al. (2000). Fully synthetic human combinatorial antibody libraries (HuCAL) based on modular consensus frameworks and CDRs randomized with trinucleotides. J Mol Biol 296, 57-86. doi:10.1006/jmbi.1999.3444

Mizuno. M., Yoshida, M., Kodama, T. et al. (2008). Effects of pre-culture conditions on the human cell line activation test (h-CLAT) results; Results of the $4^{\text {th }}$ Japanese inter laboratory study. AATEX 13, 70-82.

Natsch, A., Bauch, C., Foertsch, L. et al. (2011). The intra- and inter-laboratory reproducibility and predictivity of the KeratinoSens assay to predict skin sensitizers in vitro: Results of a ring-study in five laboratories. Toxicol In Vitro 25, 733-744. doi:10.1016/j.tiv.2010.12.014

OECD (2010). Test No. 429: Skin Sensitization: Local Lymph Node Assay. OECD Guidelines for the Testing of Chemicals, Section 4. OECD Publishing, Paris. doi:10.1787/9789264071100-en

OECD (2015). Test No. 442C: In Chemico Skin Sensitisation: Direct Peptide Reactivity Assay (DPRA). OECD Guidelines for the Testing of Chemicals, Section 4. OECD, Paris. doi:10.1787/9789264229709-en

OECD (2018a). Test No. 442D: In Vitro Skin Sensitization: ARENrf2 Luciferase Test Method. OECD Guidelines for the Testing of Chemicals. OECD, Paris. doi:10.1787/9789264229822-en

OECD (2018b). Test No. 442E: In Vitro Skin Sensitisation: human Cell Line Activation Test (h-CLAT). OECD Guidelines for the Testing of Chemicals. OECD, Paris. doi:10.1787/9789264264359-en

Sakaguchi, H., Ashikaga, T., Miyazawa, M. et al. (2006). Development of an in vitro skin sensitization test using human cell lines; human cell line activation test (h-CLAT). II. An inter-laboratory study of the h-CLAT. Toxicol In Vitro 20, 774-784. doi:10.1016/j.tiv.2005.10.014

Sakaguchi, H., Ashikaga, T., Miyazawa, M. et al. (2009). The relationship between CD86/CD54 expression and THP-1 cell viability in an in vitro skin sensitization test - human cell line activation test (h-CLAT). Cell Biol Toxicol 25, 109-126. doi:10.1007/ s10565-008-9059-9

van der Valk, J., Bieback, K., Buta, C. et al. (2018). Fetal bovine serum (FBS): Past - present - future. ALTEX 35, 99-118. doi:10.14573/altex.1705101.

\section{Conflict of interest}

None of the authors have potential conflicts of interest.

\section{Funding}

This project was self-funded by XCellR8 Ltd. 